\title{
Women Investors and the Virginia Company in the Early Seventeenth Century
}

DOI:

10.1017/s0018246x19000037

\section{Document Version}

Accepted author manuscript

Link to publication record in Manchester Research Explorer

\section{Citation for published version (APA):}

Ewen, M. (2019). Women Investors and the Virginia Company in the Early Seventeenth Century. The Historical Journal, 62(4), 853-874. https://doi.org/10.1017/s0018246x19000037

\section{Published in:}

The Historical Journal

\section{Citing this paper}

Please note that where the full-text provided on Manchester Research Explorer is the Author Accepted Manuscript or Proof version this may differ from the final Published version. If citing, it is advised that you check and use the publisher's definitive version.

\section{General rights}

Copyright and moral rights for the publications made accessible in the Research Explorer are retained by the authors and/or other copyright owners and it is a condition of accessing publications that users recognise and abide by the legal requirements associated with these rights.

\section{Takedown policy}

If you believe that this document breaches copyright please refer to the University of Manchester's Takedown Procedures [http://man.ac.uk/04Y6Bo] or contact uml.scholarlycommunications@manchester.ac.uk providing relevant details, so we can investigate your claim.

\section{OPEN ACCESS}




\title{
WOMEN INVESTORS AND THE VIRGINIA COMPANY IN THE EARLY
}

\section{SEVENTEENTH CENTURY*}

\author{
MISHA EWEN \\ University of Manchester
}

\section{WOMEN INVESTORS}

Abstract. This article explores the role of women investors in the Virginia Company during the early seventeenth century, arguing that women determined the success of English overseas expansion not just by 'adventuring' their person, but their purse. Trading companies relied on the capital of women, and yet in seminal work on Virginia Company investors women have received no attention at all. This is a significant oversight, as studying the women who invested in trading companies illuminates broader issues regarding the role of women in the early English empire. This article explores why and how two women from merchant backgrounds, Rebecca Romney (d. 1644) and Katherine Hueriblock (d. 1639), managed diverse, global investment portfolios in the period before the Financial Revolution. Through company records, wills, letters, court depositions, and a surviving church memorial tablet, it reconstructs Romney and Hueriblock's interconnected interests in 'New World' ventures, including in Newfoundland, the North-West Passage Company, Virginia colony and sugar trade. Studying women investors reveals how trade and colonization shaped economic activity and investment practices in the domestic sphere and also elucidates how women, in their role as investors, helped give birth to an English empire.

In May 1607, under the auspices of the Virginia Company's 1606 charter, English settlers landed at Jamestown and founded what was to become England's first permanent settlement in North America. The colonization of Virginia was understood 
as an undertaking of public good and honour, one that would bring prosperity and stability to the whole English nation. Virginia was believed to be a cornucopia rich in natural resources, ready for export, and also a land where England's growing population could be resettled and put to work. With territories in North America, England could challenge Catholic Spain's hegemony in the Atlantic world too, not least through the evangelization of Native Americans. ${ }^{1}$ The Virginia Company needed funds to support this venture and relied upon individuals who invested their fortunes to generate the capital needed. The company employed various financial mechanisms to fill its coffers, including prize lotteries, which were introduced from the Low Countries and first tried in England in $1568 .^{2}$ The ballad Londons Lotterie (London, 1612) was published to promote the Virginia Company's first lotteries, and one notable feature is that it aimed to attract women investors. ${ }^{3}$ Evidently the company understood the important contribution that women could make to colonization, and not just as settlers.

In the ballad, the prospect women had to win a 'fortune' was framed in relation to the female concerns of marriage, family and the household; the responsibility of managing household wealth did, after all, often fall upon women. ${ }^{4}$ Women players were promised that their winnings could provide financial security, or even increase their marriage portion:

You Maydes that have but portions small

to gaine your Mariage friend,

Cast in your Lottes with willing hand,

God may good fortune send.

You Widowes, and you wedded Wives, one litle substaunce try:

You may advance both you and yours, with wealth that comes thereby. 5 
Portrayals of women participating in lotteries to secure a marriage portion or increase their personal wealth were common in printed literature from the 1660 s onwards, yet this much earlier example encouraged women to play to further colonial enterprise. ${ }^{6}$ The gendered associations of playing at lotteries, however, were established at the time of the first English lottery, which was held in 1568 to raise money for the repair of England's harbours. ${ }^{7}$ Some of the poesies that were used to identify ticket-holders have survived, including one entered by Sibbel Cleyton, who wrote: 'I am a pore maiden and faine would marry, And the lacke of goods is the cause I tarry'. ${ }^{8}$ It is impossible to know what proportion of the sum raised by the Virginia Company lotteries came from tickets that women purchased, because the records are incomplete, but from legal records and the Virginia Company's own court minutes we do know that several participated. ${ }^{9}$ According to one allegation of fraud in the lottery, John West sent Rebecca, his maidservant, to gamble at the lotteries in Southwark and the Strand in late $1613 .{ }^{10}$ Then in October 1619, Ruth Pittman, whose age and occupation is unknown, told justices of the peace how she had been robbed of her lottery winnings (8s.) after joining with fifteen others in Wells to play. ${ }^{11} \mathrm{Mrs}$ Anthony was also fortunate at the lotteries, and attended the Virginia Company court to demand the 'prizes due unto her' from the Second Great Standing Lottery, held in $1615 .{ }^{12}$ The literary appeal of the ballad in addition to the surviving archival evidence reminds us that women had another significant role in overseas expansion: a woman could assist not just by 'adventuring' her person, but her purse.

Trading companies relied on the capital of women, and yet in seminal work on Virginia Company investors women have received no attention at all. ${ }^{13}$ This is a significant oversight, as studying the women who invested in trading companies illuminates broader issues regarding the role of women in the early English empire. Contemporaries recognised that women made an essential contribution to the establishment of English colonies as wives and mothers, but historians have overlooked the impact that women had as active investors. ${ }^{14}$ This elision has stripped 
women of their agency in a critical period of English colonial history; it was as investors and also as settlers that women shaped the fortunes of English overseas expansion. The following examination of women investors will thus add important new depth and nuance to our understanding of the relationship between gender and English colonisation in the 'New World', whilst also providing the first close study of the investment practices of women in the Virginia Company.

The nature of women's contributions to overseas trade and colonization has emerged in recent work by Susanah Shaw Romney and Amy Froide. Their work has uncovered the varied formal and informal economic activity of women that supported the establishment of early modern European empires, and shareholding in companies was often just one aspect of their diverse investment portfolios. ${ }^{15}$ Yet, whilst new research by Froide and others has shed much light on English women's investment in trade companies, lotteries, government bonds, and the newly minted Bank of England during the Financial Revolution, there has been very little study of women's roles as investors in the preceding period. ${ }^{16}$ Although the decades following the Glorious Revolution (1688) saw enormous development in financial practices and opportunities for investment, during the early seventeenth century, and in direct response to overseas trade and colonization, women also engaged in risky and innovative financial practices, such as lotteries and joint-stock companies. Across the whole early modern period English women from various social backgrounds were important financial creditors too, acting both for financial gain and social esteem. ${ }^{17}$ Rarely, however, has our understanding of their management of varied financial profiles, including borrowing and lending on interest, been integrated with histories of women's investment in overseas trade and colonization. ${ }^{18}$ This is despite growing appreciation that the activity of women in England interconnected with overseas ventures: as creditors, consumers of luxury goods, artisans, and retailers. There is little doubt that women facilitated the growth of a burgeoning English empire. ${ }^{19}$

Rebecca Romney (d. 1644) and Katherine Hueriblock (d. 1639), two women 
who financed the Virginia Company, stand out as examples of how women's social and commercial networks and expertise influenced overseas ventures. ${ }^{20}$ Investing in trading companies was an exercise in skill and status, and, as Barbara Todd has described, one method that women used to cultivate a 'public economic presence'. ${ }^{21}$ Of all women who financed the Virginia Company, an unusually rich variety of source material survives to illuminate the role of these two merchant women in overseas trade and colonization. Through company records, wills, letters, court depositions, and a surviving church memorial tablet, this article will first reconstruct Romney and Hueriblock's interest in 'New World' ventures. It adopts an interconnected approach to understand the motivations behind their investments and see them as they themselves did. Romney and Hueriblock financed colonization and trade through commercial channels, but their activity was also distinguished by their relationships with different communities in the City of London: Romney, as a godly puritan, and Conway, as a Dutch denizen. Investment in trading companies materialised for no single reason, but the social networks of individuals were certainly important in persuading people to invest, as was the desire to establish social and commercial capital. In early modern England, individuals engaged in commerce navigated the 'competing demands of public and private', and Romney and Hueriblock were certainly no exception. ${ }^{22}$ The article then turns to examine how Romney and Hueriblock used particular financial practices - specifically bonds and lotteries - to invest in the Virginia Company. By doing so, they demonstrated that they were skilled and experienced investors, and not averse to risk-taking. By exploring the financial activity of Romney and Hueriblock this article reveals how and why women managed diverse, global investment portfolios in the period before the Financial Revolution, and also how they engaged with investment opportunities in joint-stock trading companies. This article will enrich our knowledge of how some women managed their wealth in the context of overseas trade and colonization at the beginning of the seventeenth century, and also add a valuable new dimension to the 
study of gender and the English empire in the Atlantic world.

Wives, widows, and 'never married' women extended credit, sometimes on interest, to business partners, neighbours, and family in the seventeenth century, yet far fewer invested in overseas trade. ${ }^{23}$ Investing in voyages, ships, and plantations was not for the risk-averse, but joint-stock companies, like the Virginia Company and East India Company (EIC), succeeded in persuading a broader cross section of English society, not least women, to try their luck. Between 1606 and 1624 the Virginia Company attracted a huge number of investors, approximately 1,684 in total, including gentlemen and merchants, as well as yeomen and brewers. It was able to appeal to investors from various social backgrounds because, at $£ 12$ 10s., the share price was relatively affordable. Joint-stock companies by their very nature too, did not require all members to be experienced, as it was the officers of joint-stock companies who directed trade, leaving investment open, for the first time, to non-merchant wealth. ${ }^{24}$ In the early seventeenth century the interests of investors in overseas trade and colonization were, as Edmond Smith has shown, both global and connected. Investors in Virginia 'adventured' in multiple 'New World' colonial enterprises, in Newfoundland, New England, and Bermuda, and they also invested in the EIC, French, Irish, Levant, Merchant Adventurers, and Spanish companies. ${ }^{25}$ Women who invested in Virginia also sought shares in the Bermuda Company, land in Newfoundland, profits from trading in sugar, and riches from the discovery of the north-west passage. Women appraised multiple investment opportunities thinking not just of financial gain, but also of the advancement of their status as subjects and citizens.

In 1609, for the first time, the Virginia Company made its shares available for sale to a broader membership, which quickly increased its number of investors. 
Starting as an elite council in 1606, it now had hundreds of investors across England. ${ }^{26}$ That year, only two women invested: Katherine West (or Hueriblock), who bought two shares for $£ 25$, and Milicent Ramsden, who bought three shares for $£ 37$ 10s... ${ }^{27}$ Katherine Hueriblock was married to a City of London freeman of the Grocers' Company, John West, and Milicent Ramsden had a similar mercantile background. ${ }^{28}$ Born Milicent Pickerd, she married first John Worsley in 1593, then Samuel Ramsden in 1603 , who were both freemen of the Brewers' Company. ${ }^{29}$ Through her sisters, Katherine Lappidge and Ellen Parker, she had further familial connections to the Silkweavers' and Brewers' companies, whilst her kinswoman, Milicent Young, was married to Richard Young, a 'wine couper'. $3^{30}$ Later she married Oliver St John, and on 24 June 1619 sold him three shares in the Virginia Company. ${ }^{31}$ In 1612, with an expanded charter that included territory in Bermuda and authority to hold a lottery, the Virginia Company attracted a greater number of women investors. The social character of women investors diversified too, to include women of elite lineage, some who benefitted from the patronage of Queen Anna of Denmark. ${ }^{2}$ The new investors were Mistress Elizabeth Scott, who was a widow; Mary Herbert, countess of Pembroke; Margaret Clifford, countess of Cumberland; Lady Elianor Cave (sometimes Carr); Lucy Russell, countess of Bedford; Elizabeth de Vere, countess of Derby; Lady Elizabeth Carey, who invested $£ 12$ 10s.; Lady Elizabeth Grey, who invested £25; and Mary Talbot, countess of Shrewsbury, who invested £50. Countess Bedford was the only woman who officially invested in another company, when she bought shares in the Bermuda Company in 1615.33

Women were active in the life and sustainability of the Virginia Company; they bought shares, attended company court meetings and were permitted to vote. As Pamela Sharpe has noted, in joint-stock companies, women were 'on the same terms as men'. ${ }^{34}$ Other women, who were not investors, petitioned the company to collect the wages of their husbands, brothers or sons. ${ }^{35}$ As we will see, not only did women buy and exchange shares in the company, they lent it money on interest, played at, 
and possibly even defrauded, its lotteries. It is important to note too that before April 1619 the records of the Virginia Company are incomplete, as the court minutes from 1606 up until this date have not survived, making it impossible to capture all of women's involvement in company affairs. ${ }^{36}$ Yet between 1615 and 1623 we do know that at least a further fourteen women acquired shares in the Virginia Company. In the intervening years, investors had exchanged and inherited shares, drawing greater numbers of women into Virginia Company business. ${ }^{37}$

Rebecca Romney and her husband William Romney (d. 1611), a merchant and Haberdasher, had extensive commercial interests in overseas trade. William Romney, who received a knighthood in 1603 , was one of the Virginia Company's principal London investors, serving on the council in 1606 and 1609. He initially bought shares of $£ 170$ in the company, but subscribed a further $£ 75$ in 1609 to supply a voyage aimed at discovering a better route to Virginia. William Romney's investments were numerous: he was deputy governor of the EIC; director of the Merchant Adventurers; bought shares in the Spanish Company in 1604 and Levant Company in 1607; and also invested in Henry Hudson's voyages in 1610. At his death, his estate was worth $£ 15,000$, and it was Rebecca Romney, as his sole executor, who settled her husband's business..$^{8}$ One of the first things she did was arrange his funeral. They had personal ties to the Grocers' Company, and Romney successfully petitioned the company to have her husband's funeral held in its common hall. ${ }^{39}$ Through overseas trade, then, the Romneys had acquired membership of an expansive commercial community in London and so were characteristic, in this respect, of the merchant class who invested in trading companies.

As the daughter and sole heir of Robert Taylor, a Mercer and freeman of the Haberdashers' Company, Rebecca Romney would have received an education in mercantile matters at home that proved useful in her partnership with William Romney upon their marriage in $1582.4^{40}$ That William Romney chose his wife to be his sole executor is unsurprising, given that she was familiar with his business and 
possessed sufficient commercial acumen to manage his affairs. As well as arranging the funeral, she was responsible for liquidating his goods and stock, and collecting and paying his debts. ${ }^{41}$ However, he testified to her specific ability to bear this task,

...in assured trust that shee will... with a good conscience performe this my will and orderly paie all my debts and legacies and otherwise carry her self in all things hereafter like as she hath done ever heretofore with great modestie and wisdom...

It was customary for widows in the City of London to receive at least one third of their husband's estate - in Rebecca Romney’s case perhaps as much as $£ 5,000$ - but she was granted more. She inherited their house on Ironmonger Lane, a stone's throw from the Guildhall, which included a warehouse, offices, shops, and a counting house where William Romney had conducted his trade, as well as $£ 800$ in ready money. William Romney appointed overseers who were active in business too, amongst them Virginia Company investors Nicholas Ferrar (d. 1620) and Sir Thomas Myddelton (d. 1631), and the merchant Giles Parslow. His will, including the appointment of overseers with experience in commerce, suggests that William Romney expected his wife to continue a successful career as a merchant. If she should stumble, his overseers were on hand to offer their expertise and assistance. $4^{2}$

Rebecca Romney had already proved herself to be a proficient businesswoman. She had her own interests in trading companies, investing independently of her husband. The system of coverture, whereby a woman's property became her husband's upon marriage, dictated that a wife could not own her own property, including, of course, shares in a company. Yet, in early modern England, the laws of coverture were flexible and often circumvented. Women invested even when they did not have a 'formal or legalized separate property arrangement'. ${ }^{43}$ Rebecca Romney invested first in the Hudson voyages to discover the north-west passage in 1610 and then, as a widow, in the North-West Passage Company (NWPC) in 1612. The NWPC 
was chartered to establish a new route to the East Indies, so that EIC merchants could challenge Portuguese dominance in the silk and spice trades. She was one of only two women to invest in the NWPC, the other being Katherine Woodward, but Rebecca Romney was certainly an esteemed investor, as islands that were newly 'discovered' during the voyages were named after her. She was joined in this venture by individuals with high stakes in the Virginia Company: Henry, the Prince of Wales, was a patron of both ventures; Sir Thomas Smythe was a founder and governor of both companies; and Sir John Wolstenholme invested large sums in both companies too. ${ }^{44}$ Rebecca Romney was acquainted with other investors too, including the merchants Giles Parslow, Roger Dye, and Richard Wich, who were her husband's partners in trade to Spain 'and other places'. When Giles Parslow sued Rebecca Romney concerning debts from this trade, we learn that she herself 'had dealinge with the said Roger Dye for Sugers'. 45 Prosperous women like Romney, despite the social status that their wealth conferred, did not necessarily choose to refrain from participating in trade. ${ }^{46}$

Rebecca Romney's commercial expertise suggests that her investments were well considered. Her dealings in the Court of Chancery, after the death of her husband, as she settled their business, demonstrates that she was, as her contemporary Lettice Heath described her, a merchant 'of very good sort'. 47 It seems that her good 'credit' was founded on her capital as well as her reputation. ${ }^{48}$ In November 1613, we learn that Rebecca Romney had sued Lettice Heath in the common court for debts owed by her late husband Michael Heath, a citizen of London and Master of the Clothworker's Company. Upon her husband's death Rebecca Romney had set about collecting the money owed by Michael Heath for unpaid merchandize. Romney told the court that together with the other creditors John Chavells a merchant in Norwich, Richard Pope a London merchant, and Nicholas Speering a London Goldsmith, she had 'some speech togeather about their debts'. Afterwards, Romney reportedly challenged Lettice Heath's claim that she 
could not afford to pay her husband's creditors; instead she claimed that Heath 'hath sufficient assets'. Romney refused, too, as recompense, Heath's offer of what she described as 'bad and desperate debts'. Romney was clearly working effectively alongside other merchants, in her own right, to settle her financial affairs. It was an approach that paid off, as the court agreed that Lettice Heath should repay the merchants. 49

We learn as well that following the death of her husband Rebecca Romney negotiated with his partners in the Spanish Company (Giles Parslow and Richard Wich) to secure her share of their profits, calculating that she was owed $£ 1,8894 \mathrm{~s}$. 4d.. A large share of her profits (£1095), however, remained in Giles Parslow’s hands, who was now unable to repay her. Although Rebecca Romney deployed, at first, 'fair and gentle' means to recover her debts, she eventually resorted to the law and had Parslow arrested. He now sued her for his arrest and also demanded the sum of $£ 33$, which he said was promised to him by her husband in his will. She denied any knowledge of this bequest, and through her familiarity with the details of her husband's business and that of the other merchants, undermined Parslow's false allegations. Unfortunately because her deposition is undated and Parslow's bill is missing, further details of the case are unclear..$^{\circ}$ Yet through the evidence given by Rebecca Romney, and those that sued her, a picture emerges of a woman who was an influential figure in the London commercial community, respected and knowledgeable, and not to be deceived.

Rebecca Romney was not only a respected woman in London's commercial community, but amongst its godly one too. In 1642, as civil war loomed, Romney contributed a large sum of the money to the parliamentarian war effort. ${ }^{51}$ According to John Vicars, a Calvinist and presbyterian chronicler,

...the Lady Rumney (a vertuous and most charitable ancient Matron in this our Israel, inhabiting in the City of London, among many others who also offered freely and chearfully to this great work) did voluntarily and freely 
send into the treasury at Guildhall 2000 li. not in way of loane, but as a free gift; whose noble name and memory herein, me thought, was worthy at least of this my particular recording and remembrance in this place. $5^{2}$

Rebecca Romney voluntarily exceeded what was expected of her, and by doing so she confirmed her status amongst the City of London's most worthy citizens. Her 'mercantile heritage' also shaped a lifetime of charitable giving.53 On 4 September 1629 she bequeathed $£ 1,200$ to the Haberdashers' Company, of which both her father and husband were freemen, which was to be used to provide loans to young freemen, support poor scholars at Cambridge, and the poor men and widows of the Haberdashers'. Even in 1822 donations from her charity continued.54 Like many merchants too, she demonstrated concern for the lives of the poor in the City of London, bequeathing $£ 400$ to Christ’s Hospital for the maintenance of ten children and $£_{70}$ to the Bridewell house of correction. 55 Philanthropy, godliness and commerce were certainly not separate spheres in early modern England. For merchants like Rebecca Romney, it was increasingly important, in order to cement one's social standing, to make large, charitable bequests of this kind. $5^{6}$

The context of Katherine Hueriblock's investment in the Virginia Company was also embedded in London's merchant community. Yet, her social origins distinguished her from the other women who invested in the Virginia Company. She was the daughter of Giles Hueriblock (d. 1594), a Dutch merchant of Ghent, and his wife Catherine Hendriex (d. 1619), who originated from Flanders. Giles Hueriblock had resided in London since at least 1550 and was a member of the Dutch Church at Austin Friars, a connection that his daughter maintained during her lifetime. ${ }^{57} \mathrm{Her}$ first two husbands, John West (d. 1612) and Richard Fust (d. 1613), were freemen of the Grocers' Company, but in 1614 she married Sir Edward Conway (c. 1563/4-1631), a politician who had served at Brill in the Netherlands and was later Secretary of State. $5^{8}$ This social climb was unusual but not impossible, especially for widows who, 
like her, had accumulated a fortune. Indeed, when rumour of her marriage to Sir Edward Conway circulated it was said 'she is worth 5 or 6000 li'.59

Like Rebecca Romney, Katherine Hueriblock invested independently in trading companies. In 1609, she bought shares of $£ 25$ in the Virginia Company, when she was married to John West. ${ }^{60}$ As the wife of a Grocer, Katherine Hueriblock's interest in the Virginia Company built upon an existing relationship between trading and livery companies; the Grocers' Company and thirty-two of its freemen had been named as shareholders in the 1609 charter. ${ }^{61}$ She maintained ties to the Grocers' Company, and bequeathed it $£ 20$ in her will to engrave her name and arms on a silver gilt plate 'for a loving remembraunce unto them for ever'. Katherine Hueriblock also gave the Grocers' Company $£ 1,200$ 20s. to assist the widows and poor children of Grocers, whilst a Grocer’s wife, Mrs Boxe, received £100 to buy a ring or jewel in remembrance. ${ }^{62}$ At the end of the seventeenth century some of the money she had gifted to the Grocers' Company was still being disbursed: £25 each year, amongst the poor in parishes in London and Warwickshire. ${ }^{63}$ In her parish church, spaces that typically served as 'theatres of memory' for the charitable works of citizens, Katherine Hueriblock left a material reminder of her philanthropy too. ${ }^{64}$ Her memorial tablet survives in St Mary's, Acton, reciting her bequests to the poor and the Dutch Church, with a poem that reads,

The poore who did thy life with prayers befreind, And on thy funerall herse in teares Attend Shew their devotion still and send on high Their prayses for thy blessed charitie May thy example others teach to give, That when they die their same (like thine) may live. ${ }^{65}$

Katherine Hueriblock certainly sought to enhance her own good reputation as a widow of the Grocers' Company and daughter of the Dutch Church, one that endured 
for many years.

Hueriblock maintained her familial connection to the Dutch Church of Austin Friars, which was the heart of the Dutch commercial community in London. In 1617 there were 230 Dutch merchants in London and the majority of the church's elders and deacons, between 1603 and 1642, were merchants too. Amongst the congregation, for example, was the financier Peter Van Lore, a Virginia Company investor who bought shares worth $£ 112$ 10s. in $1618 .{ }^{66}$ Hueriblock's father, Giles Hueriblock, was a deacon there in 1550 and she joined the congregation herself in 1637, though she certainly would have worshipped at the church before this date. In the final years of her life, she gifted $£ 30$ to the church in 1636 and $£ 2$ in 1637, and bequeathed an endowment of $£_{300}$ to the church in her will. ${ }^{67}$ From surviving personal correspondence, we know that Katherine Hueriblock established relationships with other churchgoers too. In 1628, Sir Edward Conway wrote a letter to Louisa Cool (or Cole, as he addressed her), in which he said "my wife your countrywoman hath given mee verie worthie reports of you' [sic]. Mrs Cool was, like Hueriblock, the daughter of an elder of the Dutch church, and also the wife of Jacob Cool, the nephew of the Dutch geographer and mapmaker Abraham Ortelius. ${ }^{68}$ Thus, Katherine Hueriblock's interest in Virginia could have sprung from her connections either to the Grocers' Company or Austin Friars. In the City of London, the livery companies and stranger churches were fertile ground for investment and interest in overseas ventures.

If communities in London helped to generate interest in trade and colonization, an education in how to handle such business began at home. During her time growing up in a Dutch household and upon marrying, Katherine Hueriblock would have built up knowledge and experience of conducting business. It was often noted in the early modern period that Dutch women were exceptionally literate and numerate, trained so that they could effectively support their merchant husbands in commerce. ${ }^{69}$ Through her parents, Katherine Hueriblock would have learned more 
than the rudiments of trade. Giles Hueriblock was a merchant, but it seems that her mother Catherine Hendriex had her own business in the production and retail of lace, a trade with which the Dutch alien community, women especially, were associated.70 In 1619, the widowed Catherine Hendriex bequeathed her stock in the lace-dyeing business to her granddaughter, and Hueriblock's niece, Katherine van Belle, who she had probably trained in the same industry. ${ }^{71}$ Women with the right skills could successfully keep family businesses going for years, passing on knowledge, property and capital. ${ }^{2}$ Moreover, from where she lived on Petticoat Lane, a place known for the production of luxury textiles, Hendriex was certainly in the perfect location to grow her enterprise. 73

Upon her marriage to John West, Katherine Hueriblock would have been expected to assist her husband in business, as joint management between husband and wife, especially in entrepreneurial trades, was common. ${ }^{74}$ Indeed, John West made Hueriblock and his son the joint-executors of his will, suggesting that he planned for her to keep his 'shop' either with his son or her new husband, when she should remarry. Hueriblock's second match with Richard Fust, another Grocer, was, therefore, mutually beneficial. 75 The knowledge that Hueriblock had of such trades would have made investing in the Virginia Company personally appealing for several reasons. Virginia was not only a potential new market for trade with settlers who would need to be supplied with all manner of goods, but the source of valuable produce that could be sold wholesale by merchants in England: dyestuffs for the lace industry, for example, or tobacco. ${ }^{76}$

Katherine Hueriblock's marriage to Sir Edward Conway, and subsequent elevated social status, might have spelled the end of her direct involvement in business, but this was not the case. A series of letters she received show that she was mediating with individuals, who were apparently her own associates, to secure an investment in the Newfoundland Company. It was not unusual for a woman to broker investment on the behalf of her family during the Financial Revolution, as Amy 
Froide has noted. ${ }^{77}$ Yet, Katherine Hueriblock was doing something quite different: she was brokering interest in a fledging colony. Sir Edward Conway had joined the Virginia Company in 1609 and bought shares in the Guiana Company in 1627. By 1628 , however, it seems, the couple were interested in expanding their interests in the Atlantic world. ${ }^{78}$ In 1628, Katherine Hueriblock corresponded with two associates, Dr James Meddus and William Payne, about investment in Newfoundland. This was the same year that the governor of the Newfoundland Company, John Slany, was trying to attract new investment. Interest in the venture had declined as colonists struggled to find a new commodity, other than fish, to market. ${ }^{99}$ Hueriblock had known Dr Meddus, who also invested in the Virginia Company in 1609, since at least 1613 when he witnessed her husband Richard Fust's will and received 40s.. Then in 1624, Meddus petitioned Sir Edward Conway concerning a protestant kinsman. ${ }^{80}$ William Payne's connection is less clear. He was a merchant from London, who had previously invested in the NWPC, and corresponded with Sir Edward Conway in 1626 about his 'inventions' of 'magna potentia et benedictio' (or 'great power and blessing'). They concerned colonial produce in Virginia and Bermuda: corn, indigo, tobacco, 'liquor of figges', and 'Porhun root'. He even had a proposal to 'brew beer for shipping at a cheap rate that shall dure a whole year or longer not growing sower nor decraying'.${ }^{81}$ Whilst Payne's connection to Katherine Hueriblock and her husband is unclear, he was known to Meddus, and as a London merchant may have had shared acquaintances with Hueriblock from her earlier life. ${ }^{82}$

Although Sir Edward Conway had previously corresponded with both Meddus and Payne, it was Katherine Hueriblock who took control of bidding for interest in the Newfoundland Company. On 2 November 1627, Payne wrote to her, 'for matters of Newfoundland I could wish that my lord himself or some of his did come in for a pportion in the lot of St Johnes'. He described it as 'the principall prime and chief let in all the whole countrey in wch is great hope of good comodities'. It was said that the 
'yre' (iron) was already 'broken' and 'some howses all reddy built'. He advised Hueriblock that her husband should write to John Slany directly, 'of his desire for coming into that lot'. ${ }^{83}$ This letter indicates that it was not the first time, then, that they had spoken about colonization in Newfoundland. Hueriblock's correspondence with Meddus also suggests that she was taking the lead in arranging the couple's interest in Newfoundland. He wrote to her on 27 June 1628 that 'According to your noble Comannds unto me... I have not beene unmindefull of the Newe found land businesse'. He expressed his 'wish by any meanes it may be proceeded in, being a businesse of so great future hopes by iron, ore and a most rich silver mine, beside the present profit of fishing, furres, and sarsaparilla'. ${ }^{84}$ Meddus wrote to Hueriblock again the following month, assuring her 'I have not been unmindefull to solicite ye Newfound land businesse'. This letter was delivered by Meddus's wife, who was, he wrote, 'now comeing to doe her service', and so she performed her own role in brokering interest in colonization. ${ }^{85}$ Despite this correspondence, there is no evidence that Hueriblock and Conway invested. ${ }^{86}$ Yet Hueriblock's exchanges with Meddus and Payne, as well as her direct investment in the Virginia Company, show that she had broader interests in North American colonization and trade. Arguably her education and training equipped her with the confidence and knowledge to pursue such ventures, including on her husband's behalf.

\section{II}

Rebecca Romney and Katherine Hueriblock made full use of the different financial mechanisms on offer in the early seventeenth century to increase their capital. There were several ways that they could profit from the Virginia Company, including lending on interest and gambling at its lotteries. Neither method was entirely riskfree, something that they both, as we will see, experienced first-hand. In the early years of the Financial Revolution women were not necessarily averse to such dangers, 
but rather opted to speculate and hazard their gains. Some even manipulated the financial tools in place to their own ends, including defrauding state lotteries. ${ }^{87}$ Rebecca Romney and Katherine Hueriblock similarly took steps to make a profit that were without guarantee, testing their own financial acumen in the process.

Around eleven years after she was widowed, Rebecca Romney grasped an opportunity to support the Virginia colony by giving a loan to the company. Women were important creditors who expected to grow a profit and increase their social status in return. ${ }^{88}$ Between May 1622 and 1623, an audit of the Virginia Company's accounts show that John Ferrar (d. 1657) had given 'bonds' to Romney for £200, a loan that the Virginia Company said would be used to make provisions for the fort at Jamestown. Ferrar must have known Romney through her relationship to his deceased father, Nicholas Ferrar, an overseer of her husband's will. This was not the first time that Romney had extended credit to the company either; in December 1620 she loaned $£ 110$ to help supply the ships Bona Nova and Abigail, at a time when the company was, according to its own accounts, awaiting new funds from the lottery. It is evident that Romney was adept at managing her finances and conducting business of this kind. On 5 March 1621, the company recorded a payment of $£ 2$ 15s. interest on the loan; she had negotiated a rate of 9 per cent interest, and they owed her for the first three months. ${ }^{89}$ It was only in 1571 that the first maximum interest rate for loans was set at 10 per cent, which fell to 8 per cent in $1624 .{ }^{90}$ Therefore, Romney offered the Virginia Company terms that were favourable to her. Through this alternate way of investing, Romney was enveloped in colonial business, but it was not necessarily a risk that paid off. There is no evidence in the company records that she received back her loan (with interest). As the Virginia Company was dissolved just one year after her latest loan, it is unlikely that she did. If Romney regained the money through the court or by informal 'fair and gentle' means, no record has survived. Nonetheless, her continued wealth, which meant she could gift the Haberdashers' Company £1,200 in 1629, suggests that she did not suffer too badly from this investment.91 
Romney's charitable giving can in fact provide further context to her loan. She may have struck up her financial relationship with the Virginia Company in late 1620 not just because of her commercial connections, but because of her philanthropic and religious outlook too. In this period, poor children from the streets of London, as well as Bridewell and Christ's Hospital, were transported to the colony in a practice that was deemed kind and charitable. As she gave money to both these institutions herself, she may have been persuaded to assist the company..$^{92}$ Her status as a 'matron' amongst London's puritan community was also significant, and may explain why Romney was prepared to loan money to the Virginia Company at the particular time that she did. Perhaps it was coincidental, but Romney agreed her first loan to the company in December 1620, at the same time that Thomas Brewer, a Brownist, was garnering puritan support to get Sir Edwin Sandys, a Virginia Company director and previously its treasurer, re-elected to the House of Commons. ${ }^{93}$ Brewer's support emerged following the correspondence he had shared with Sandys about the settlement of Leiden Separatists in Virginia. Romney must have known of the company's attempts to settle Separatists in the colony, so that her decision to participate in Virginia business may have been shaped by the wider puritan support that the company received.94 Thus, Romney's interest in the Hudson voyages and NWPC, as well as the Virginia Company, demonstrates that she was 'invested' in North America in multiple senses. She was not a passive investor: rather she actively managed her investments and demonstrated that she had the knowledge and skill to profit from overseas ventures, as she demonstrated during her widowhood, and according to William Romney even beforehand, several times. ${ }^{95}$

As well as buying shares, Katherine Hueriblock used the Virginia Company's lotteries to increase her wealth. She was alleged to have defrauded the lotteries, along with her stepson John West, who was the lottery manager, in the period between August and November $1613 .{ }^{96}$ This was several years after she had invested $£ 25$ in the company, and lack of confidence in the colony meant that many investors had since 
defaulted. By 1620, the Virginia Company reported that $£ 16$,ooo was uncollected from subscribers, but the problem started as early as $1612 .{ }^{97}$ Katherine Hueriblock might have decided to take matters into her own hands to guarantee a return on her investment. The shop that she had inherited from her first husband was co-managed with her stepson, and it was this property that came under the scrutiny of the complainant, Walter Fitzwilliam, in January 1615. At the Court of Star Chamber, Fitzwilliam alleged that John West had committed fraud with his associate John Webb, an attorney. The Virginia Company had charged West and the joint manager Richard Bartlett, also a citizen and merchant of London, with the 'safe keeping of all the said lotts', and each had a key to the chest where the lots were kept. Yet Fitzwilliam claimed that West had

...obtayne[d] into his custodie thother key of the chest where the lotts were ... having by this meanes gott both the said keyes into his custodie ... then neither regarding the trust reposed in him, not the wellfare of the said plantation and good of that your majesty's service: But being led away with a ... desire of gaine did practice ... with Charlotte his then wife ... Katherine now the wief of $\mathrm{Sr}$ Edward Conewaye kt: and one John Webb an Attorney of the Lawe, how they should gaine \& benefitt of the said 240oli. in prizes in the said lottarie to their owne private uses \& defraud all yr maj sub which should adventure in the said lottarie...

The lottery chest and prizes were said to have been taken to the shop in Mincing Lane, where West and his 'confederates', amongst them Katherine Hueriblock, took 'all the lotts of prizes ontop the said chest to the value of 20ooli. upward and did onlie leave therein some smale prized lotts'. For Fitzwilliam to plausibly accuse Hueriblock of involvement suggests that, at the very least, she was still co-managing business with West during the time that he was working for the company; at the worst, it seems that she was complicit in West's scheme to defraud lottery players, an 
accusation that both he and John Webb denied. They declined to answer the charges, unless compelled to by the court. The 'ordering of a lottery' was not 'fitt for the dignity of theis... court to examine', they said; rather, it did 'belonge to the treasurer and company of adventurers and planters of the city of London for the first colony in Virginia'. ${ }^{98}$ The company, it seems, did not pursue the matter.

Katherine Hueriblock was not the only woman to be accused, of course, but also Charlotte West, John West's deceased wife, and Rebecca, his maidservant. Fitzwilliam claimed that Rebecca had operated with Dutch and French 'strangers' in the City of London to carry out her crimes. No doubt this was meant to even further condemn the character of the 'confederates', but it might also reveal Fitzwilliam's scorn towards Hueriblock's origins and John West's association, through his stepmother, to the Dutch community in London. Dutch businesses, and the active role of Dutch women within them, were often met with hostility in early modern London. ${ }^{99}$ Moreover, if Dutch and French aliens really did help the household to defraud the Virginia Company lottery, then it might have been Hueriblock who recruited them. Certainly she had the connections and no doubt she had more experience than her associates with how lotteries worked. That lotteries were popular in the Low Countries was widely known. ${ }^{100}$ We might wonder, then, why she would risk her reputation in this way. If we believe Fitzwilliam's sequence of events, at the time of the fraud Katherine Hueriblock was married (for the second time) to Richard Fust, though she would soon be widowed, and remarried to Sir Edward Conway by the time the charges were brought. There is no reason to believe that she was destitute, indeed she had recently inherited $£ 2,800$ from her first husband, John West. ${ }^{101}$ Perhaps her outlook meant that she did not flinch from this opportunity, even if it was high-risk. Katherine Hueriblock's years of experience growing up in a Dutch mercantile household, then her marriages to two freemen of the Grocers' Company in succession, gave her with the knowledge and networks to succeed in commerce and finance, and perhaps even manipulate the innovative models in place. 
The Virginia Company was dissolved in 1624 and the colony was brought under crown control, but up until this date women had played an active role in the company's affairs: they bought shares, attended and petitioned at court meetings, financed it when it was desperate for capital, played at and maybe even defrauded its lotteries. In 1633, what remained of the Berkeley Hundred planters wanted to begin a 'new venture' in Virginia. Writing to John Smyth, Richard Berkeley recounted his recent attempts to acquire new investment in Gloucestershire. He had raised $£ 165$ so far from four associates and a further $£ 120$ was noted next to his own name. He told Smyth though, 'I will not beguile you, it is not all mine owne; some friendes ( 2 of them gentlewomen) were willing to go along with me in the adventure, but would not have their names seene in the booke'. ${ }^{102}$ Women's investment, which furnished overseas ventures with social capital and actual funds, remained much needed. Yet, the elision of women in surviving records and in the work of historians has obscured the full extent of women's enterprise in overseas trade and colonization, leading us to question, how many more invested in similarly unseen ways?

Through a close reading of company, court, and personal archives, this article has considered why, and demonstrated how, two women 'adventured' in trade and colonization. The exact motivations for women's investment eludes us, but whether it was for profit or out of duty, their social, commercial, and epistolary networks can suggest how they were drawn into investing. The commercial experience of Rebecca Romney and Katherine Hueriblock provides a revealing lens onto the broader social, cultural, and economic issues that prompted investment in the 'New World'. Both women were respected in their communities, so the civic and national prestige that was associated with investing in overseas ventures, as well as its supposed philanthropic merit, no doubt attracted them. The ways that Romney and Hueriblock 
invested their money also required skill and acumen. At the time they invested, they were women who were well-practiced in financial management, with a lifetime of experience in commerce behind them: Hueriblock was perhaps forty-four when she bought shares in the Virginia Company in 1609 and forty-eight when she allegedly defrauded the lotteries in 1613, and Romney was also middle-aged when she loaned the company money in $1620 .{ }^{103}$ In the course of the seventeenth century, more women would adapt to new financial tools, such as joint-stock companies and lotteries, plotting new ways to increase their wealth.

The histories of Romney and Hueriblock prompt us to think more widely about the role of women in trading companies and the economy of the English empire in the early seventeenth century. In this period, women actively managed global investment portfolios, and took advantage of expanding opportunities for trade and colonization. For the first time, women accrued and managed household wealth that was generated through the exploitation of people and land in English overseas colonies. Without considering the role of women, then, how wealth from the 'New World' was created and then circulated in England cannot be fully understood. Studying women investors reveals how trade and colonization shaped economic activity and investment practices in the domestic sphere during the early seventeenth century. Yet, it also elucidates how women helped give birth to an English empire: women 'adventurers' are central to the early modern colonial legacy in more ways than one.

Department of History, School of Arts, Languages and Cultures, The University of Manchester, Oxford Road, Manchester, M13 9PL misha.ewen@manchester.ac.uk

* Aske Brock, Amy Froide, Sasha Handley, Jason Peacey, Susanah Shaw Romney, and Edmond Smith all offered feedback, encouragement and valuable insight at many different stages of this research. I would also like to thank the anonymous reviewers of this journal for their comments. The completion of this research was only made possible by generous funding from the Arts and Humanities Research Council 
(University College London) and the Leverhulme Trust (University of Kent), as well as short-term fellowships at the Huntington Library and Folger Library.

${ }^{1}$ There is a large body of scholarship on the English colonization of Virginia in the late-sixteenth and early-seventeenth centuries. See, L. H. Roper, The English empire in America, 1602-1658: Beyond Jamestown (London, 2009); Karen Ordahl Kupperman, The Jamestown project (London, 2007); Andrew Fitzmaurice, Humanism and America: An intellectual history of English colonisation, 150o1625 (Cambridge, 2003); and James Horn, Adapting to a New World: English society in the seventeenth-century Chesapeake (London, 1994).

2 David Dean, 'Elizabeth's lottery: Political culture and state formation in early modern England', Journal of British Studies, 50 (2011), pp. 586-611, at pp. 590-1.

3 Anon., Londons Lotterie: With an incouragement to the furtherance thereof, for the good of Virginia, and the benefite of this our native Countrie; wishing good fortune to all the venture in the same. To the tune of Lusty Gallant (London, 1612; STC 16756.5). Also, Robert C. Johnson, 'The lotteries of the Virginia Company', Virginia Magazine of History and Biography, 74 (1966), pp. 259-292.

4 Alexandra Shepard, 'Making their own business: Married women and credit in early eighteenthcentury London', Transactions of the RHS, 25 (2015), p. 55.

5 Anon., Londons Lotterie.

${ }^{6}$ See discussion in Amy Froide, Silent partners: Women as public investors during Britain's Financial Revolution, 169o-175o (Oxford, 2017), ch. 2.

7 Dean, 'Elizabeth's lottery'.

${ }^{8}$ C. L'Estrange Ewen, Lotteries and sweepstakes: An historical, legal, and ethical survey of their introduction, suppression and re-establishment in the British Isles (London, 1932), p. 59.

9 One surviving document notes that on 27 May 1615 in High Wycombe the mayor and thirty citizens, including women and children, contributed $£ 12$ 13s. 4d. towards the lottery. R. W. Greaves, ed., The first ledger book of High Wycombe (Welwyn Garden City, 1947), p. 109.

10 TNA, Fitzwilliam v. West, Jan. 1615, STAC 8/144/6, fos. 1-2.

${ }^{11}$ Somerset Record Office, Examination, 20 Oct. 1619, Q/SR/34/91.

${ }^{12}$ Dated 12 Jan. 1620. Susan Myra Kingsbury, ed., The Records of the Virginia Company of London (5 vols., Washington, DC, 1906-1935), i, p. 295.

${ }_{13}$ Theodore K. Rabb, Enterprise and empire: Merchant and gentry investment in the expansion of England: 1575-1630 (Cambridge, MA, 1967); Wesley Frank Craven, The dissolution of the Virginia Company: The failure of a colonial experiment (New York, NY, 1932); Wesley Frank Craven, The 
Virginia Company of London, 1606-1642 (Williamsburg, VA, 1957); Robert Brenner, Merchants and revolution: Commercial change, political conflict, and London's overseas traders, 1550-1653 (Cambridge, 1993). On women in the East India Company, see Pamela Sharpe, 'Gender at sea: Women and the East India Company in seventeenth-century London', in Penelope Lane, Neil Raven \& K. D. M. Snell, eds., Women, work and wages in England, 1600-1850 (Martlesham, 2004).

${ }^{14}$ Sarah M. S. Pearsall, 'Gender', in David Armitage and Michael J. Braddick, eds., The British Atlantic world, 150o-18oo (Basingstoke, 2002), pp. 114-115; David R. Ransome, 'Wives for Virginia, 1621', William and Mary Quarterly, 48 (1991), pp. 3-18; Lois Green Carr and Lorena S. Walsh, 'The planter's wife: The experience of white women in seventeenth-century Maryland', William and Mary Quarterly, 34 (1977), pp. 542-571; and Kathleen M. Brown, Good wives, nasty wenches, and anxious patriarchs (Chapel Hill, NC, 1996). For women in Dutch colonies, see Susanah Shaw Romney, “With \& alongside his housewife": Claiming ground in New Netherland and the early modern Dutch empire', William and Mary Quarterly, 73 (2016), pp. 187-224.

15 Susanah Shaw Romney, New Netherland connections: Intimate networks and Atlantic ties in seventeenth-century America (Chapel Hill, NC, 2014); Froide, Silent partners, pp. 64-5.

${ }^{16}$ Froide, Silent partners; Ann M. Carlos and Larry Neal, 'Women investors in early capital markets, 1720-1725', Financial History Review, 11 (2004), pp. 197-224; and Anne L. Murphy, 'Lotteries in the 1690s: investment or gamble?', Financial History Review, 12 (2005), pp. 227-246, at pp. 238-9.

${ }_{17}$ Eleanor Hubbard, City women: Money, sex, and the social order in early modern London (Oxford, 2012), p. 189; Amy M. Froide, Never married: Singlewomen in early modern England (Oxford, 2005), ch. 5 .

${ }^{18}$ Judith Spicksley, 'Usury legislation, cash, and credit: The development of the female investor in late Tudor and Stuart periods, The Economic History Review, 61 (2008), pp. 277-301, at p. 297. Other key works on women and credit in early modern England include: Judith Spicksley, “Fly with a duck in thy mouth": Single women as sources of credit in seventeenth-century England', Social History, 32 (2007), pp. 187-207; Craig Muldrew, “'A mutual assent of her mind”? Women, debt, litigation and contract in early modern England', History Workshop Journal, 55 (2003), pp. 47-71; Jane Whittle, 'Enterprising widows and active wives: Women's unpaid work in the household economy of early modern England', The History of the Family, 19 (2014), pp. 283-300; Shepard, 'Married women', pp. 53-74; Alexandra Shepard, 'Crediting women in the early modern English economy', History Workshop Journal, 79 (2015), pp. 1-24.

${ }_{19}$ Muldrew, 'Contract in early modern England', p. 48; Spicksley, 'Female investor', p. 289; Spicksley, 'Single women', p. 187; Richard Grassby, Kinship and capitalism: Marriage, family, and business in the 
English-speaking world, 1580-1740 (Cambridge, 2001), p. 332; Pamela Sharpe, 'Gender in the economy: Female merchants and family businesses in the British Isles, 1600-1850', Social History, 34 (2001), pp. 283-306, at p. 294

${ }^{20}$ As the records for Katherine Hueriblock span her three marriages - to John West, Richard Fust and Sir Edward Conway - her unmarried name is used throughout for clarity.

${ }^{21}$ Barbara Todd, 'Property and a woman's place in Restoration London', Women's History Review, 19 (2010), pp. 181-200, at pp. 182, 188.

22 Perry Gauci, The politics of trade: The overseas merchant in state and society, 1660-1720 (Oxford, 2001), pp. 78-9. On how membership to corporations enabled individuals to exercise 'social capital', see Phil Withington, Society in early modern England: The vernacular origins of some powerful ideas (Cambridge, 2010), p. 205; and Sheilagh Ogilvie, Institutions and European trade: Merchant guilds, 100o-180o (Cambridge, 2011), p. 7.

23 Froide, Never married, pp. 134-8.

24 See Rabb, Enterprise and empire, pp. 59-61, 104. Because of the steep price of membership to the EIC (£200), less experienced investors would sometimes 'adventure' together with more experienced merchants. See Edmond Smith, 'Networks of the East India Company, 1600-1625' (PhD thesis, Cambridge, 2015), ch. 2.

25 Edmond Smith, ‘The global interests of London's commercial community, 1599-1625: Investment in the East India Company', Economic History Review, https://doi.org/10.1111/ehr.12665, at n. 5, pp. 13-5. ${ }^{26}$ The Second Charter of Virginia (1609), in Brown, ed., Genesis of the United States, i, pp. 206-37; and Kupperman, Jamestown project, pp. 242-43.

${ }^{27}$ Kingsbury, ed., Records, III, pp. 87, 89.

${ }_{28}$ TNA, Will of John West, Grocer of London, 10 Sept. 1613, PROB 11/122/205.

${ }^{29}$ London Metropolitan Archives (LMA), Parish registers: St Giles Cripplegate, City of London, 17 Apr. 1593, P69/GIS/A/oo2/MSo6419/o01; and LMA, Marriage allegations, Diocese of London, 7 Mar. 1603, DL/A/D/o02/MS10091/o02.

${ }^{30}$ Thomas Lappidge was a Silkweaver, and William Parker a Brewer. LMA, Will of Samuel Ramsden, Gent., 20 Oct. 1606, MS 9172/23B; TNA, Will of John Worsley, Brewer, 26 Aug. 1603, PROB 11/102. Milicent Young had a daughter, Dorcas Worsley, indicating that these women were the kin of John Worsley. TNA, Will of Milicent St John, widow of West Kington, Wiltshire, 11 May 1636, PROB $11 / 171 / 70$.

${ }^{31}$ Kingsbury, ed., Records, i, p. 235, III, p. 6o. For her marriage to St John in 1609, Wiltshire and Swindon History Centre, Act Book, 20 Dec. 1609, D1/39/1/37, fo. 130. 
$3^{2}$ They included the countesses of Bedford, Pembroke, and Derby. Roper, English empire, pp. 74, 77-8. 33 The Third Charter of Virginia (1612) in Brown, ed., Genesis of the United States, ii, pp. 540-53; also the complete list of shareholders in 1618, with amount of stock, in Kingsbury, Records, iii, pp. 79-90. For Bedford's investment in the Bermuda Company, see Helen Payne, 'Russell [née Harrington], Lucy, countess of Bedford (bap. 1581, d. 1627)', ODNB.

34 Sharpe, 'Gender at sea', p. 58.

35 Kingsbury, Records, i, p. 497.

${ }^{36}$ The first two court books (28 Jan. 1606-14 Feb. 1615 and 31 Jan. 1615-28 Apr. 1619) were in the Virginia Company's possession in 1623, but no record of them afterwards has survived. See Kingsbury, Records, i, pp. 22, 25. Note that Kingsbury mistakenly gives the end date of the second book as 28 July, rather than 28 April.

37 For the exchange of shares in the Virginia Company between 1615 and 1623, and women's shareholding, see Kingsbury, Records, iii, pp. 58-66, 83 .

${ }^{38}$ Rabb, Enterprise and empire, p. 368; James McDermott, 'Romney, Sir William (d. 1611)', ODNB; Martha W. Hiden, 'A Voyage of Fishing \& Discovery 1609', Virginia Magazine of History and Biography, 65 (1957), pp. 62-66, at p. 64; TNA, Will of Sir William Romeny, 9 May 1611, PROB $11 / 117 / 496$.

39 Including an overseer of his will, Sir Thomas Myddelton, and the merchant Roger Dye, discussed below. See GL, Grocers' Company court minute book, undated May 1611, CLC/L/GH/B/o01/MS11588/oo2, fo. 632.

$4^{40}$ TNA, Will of Robert Taylor, Mercer of London, 21 Oct. 1592, PROB 11/80/301; LMA, Parish registers: St Magnus the Martyr, 5 Feb. 1582, P69/MAG/A/o01/MSo11361. On women's work with their male relations, Amy Louise Erickson, 'Married women's occupations in eighteenth-century London', Continuity and Change, 32 (2008), pp. 267-307, at p. 290; and Ariadne Schmidt, 'The profits of unpaid work. "Assisting labour" of women in the early modern urban Dutch economy', The History of the Family, 19 (2014), pp. 301-22, at p. 306.

${ }^{41}$ Grassby, Kinship and capitalism, p. 132.

$4^{2}$ TNA, Will of Sir William Romeny, 9 May 1611, PROB 11/117/496. Also, Amy Erickson, Women and property in early modern England (London, 1993), p. 27; and D. J. Keene and Vanessa Harding, 'St. Martin Pomary 95/13-15', in Historical gazetteer of London before the Great Fire Cheapside; Parishes of All Hallows Honey Lane, St Martin Pomary, St Mary Le Bow, St Mary Colechurch and St Pancras Soper Lane (London, 1987), pp. 169-179, available BHO [http://www.british-history.ac.uk/no- 
series/london-gazetteer-pre-fire/pp169-179]. On widows continuing in trade, see Schmidt, "Assisting labour"', p. 315 .

43 Froide, Silent partners, pp. 101, 106; Krista J. Kesselring and Tim Stretton, 'Introduction: Coverture and continuity', in Krista J. Kesselring and Tim Stretton, eds., Married women and the law: Coverture in England and the common law world (Montreal, 2013), p. 12; Amy Louise Erickson, 'Coverture and capitalism', History Workshop Journal, 59 (2005), pp. 1-16; Marjorie K. McIntosh, ‘The benefits and drawbacks of femme sole status in England, 1300-160o', Journal of British Studies, 44 (2005), pp. 410438.

${ }_{44}$ Christy Miller, ed., The voyages of Captain Luke Foxe of Hull, and Captain Thomas James of Bristol, in search of a northwest passage, in 16131-32: with narratives of the earliest northwest voyages of Frobisher, David, Weymouth, Hall, Knight, Hudson, Button, Gibbons, Bylot, Baflin, Hawkridge, and others (2 vols., London, 1894), i, p. 149. For Lady Romney's investments, see Rabb, Enterprise and empire, p. 368. For the North-West Passage Company charter and its investors, see W. Noel Sainsbury, ed., Calendar of state papers colonial, East Indies, China and Japan, 1513-1616 (5 vols., London, 1864), ii, pp. 238-41.

45 Her dealing in sugar must have occurred sometime before 1620 when Roger Dye died. So although this case is undated, we can posit it was between 1611 and 1620. TNA, Parslow v. Romney, undated, C 2/JasI/P7/47; TNA, Will of Sir William Romeny, 9 May 1611, PROB 11/117/496; TNA, Will of Roger Dye, Grocer of St Magnus, City of London, 18 Oct. 1620, PROB 11/136/321.

${ }^{46}$ For discussion, see Erickson, 'Married women's occupations', p. 282.

47 TNA, Heath v. Romney, 7 Nov. 1613, C 2/JasI/H1/52, fo. 1.

${ }^{48}$ Muldrew, 'Contract in early modern England', p. 53.

49 Membership to the Livery Companies was found using 'The Records of the London Livery Companies Online' (ROLLCO) <http://www.londonroll.org>; TNA, Heath v. Romney, 23 Nov. 1613, C 2/JasI/H1/52, fo. 2.

$5^{50}$ TNA, Parslow v. Romney, undated, C 2/JasI/P7/47.

${ }^{51}$ John J. Schroeder, 'War finance in London, 1642-1646', The Historian, 21 (1959), pp. 356-371, at pp. $358-9$.

$5^{2}$ John Vicars, God on the mount, or a continuation of England's parliamentary chronicle (London, 1643), p. 128.

53 Todd, 'Property and a woman's place', pp. 185, 197. 
54 City of London Livery Companies Commission, City of London Livery Companies Commission. report (5 vols., London, 1884), iv, pp. 457-477; M. Sherwood, ed., The endowed charities of the City of London (London, 1829), pp. 502-3; McDermott, 'Romney, Sir William’, ODNB.

55 W. K. Jordan, The charities of London 1480-166o: The aspirations and the achievements of the urban society (London, 1960), pp. 255, 398; McDermott, 'Romney, Sir William', ODNB.

${ }^{56}$ Jordan, Charities of London, p. 106.

57 William John Charles Moens, ed., The marriage, baptismal, and burial registers, 1571 to 1874, and monumental inscriptions, of the Dutch Reformed Church, Austin Friars, London (Lymington, 1884), p. 211; Ole Peter Grell, Dutch Calvinists in early Stuart London: The Dutch Church in Austin Friars, 16031642 (New York, 1989), pp. 52, 299; and E. G. Kirk and E. F. Kirk eds., Returns of aliens dwelling in the city and suburbs of London from the reign of Henry VIII to that of James I (Aberdeen, 1900-o8), ii, pp. 162, 187, 203, 207, 209, 254, 275, 340, 411, 414, 442. Also, TNA, Will of Giles Hueriblock or Hueriblocke, Merchant of City of London, 2 Nov. 1594, PROB 11/84/311; and TNA, Will of Catharyne Hendriex, widow of Stepney, Middlesex, 12 Feb. 1619, PROB 11/133. Note that there were variant spellings of Catherine Hendriex.

$5^{8}$ TNA, Will of John West, 10 Sept. 1613, PROB 11/122/205; TNA, Will of Richard Fust, Grocer of Saint Clement, City of London, 9 Mar. 1614, PROB 11/123/266; Sean Kelsey, 'Conway, Edward, first Viscount Conway and first Viscount Killultagh (c. 1564-1631)', ODNB.

${ }^{59}$ For the marriage prospects of wealthy widows, see Grassby, Kinship and capitalism, p. 140. Quote from TNA, Graye Conyers to Francis Conyers, 13 Mar. 1614, Chiswick, State papers, 14/76, fo. 93.

${ }^{60}$ It is difficult to distinguish whether it was her husband or stepson (of the same name) who also bought shares in the Virginia Company in 1609. A John West also invested in the Spanish (1604), Irish (1609) and Bermuda (1615) companies. It was certainly John West (the son) who invested in the Bermuda Company, because by this date his father was dead. See Rabb, Enterprise and empire, p. 400. ${ }^{61}$ There are fifty-six livery companies listed. See The Second Charter of Virginia (1609), in Brown, ed., Genesis of the United States, i, pp. 206-37.

${ }^{62}$ Mrs Boxe may have been the widow of Henry Boxe who witnessed John West's will. A Mr Boxe also mediated with the Grocers' Company concerning Lady Conway's bequest. See TNA, Will of Dame Katherine Viscountess Conway, widow, 19 July 1639, PROB 11/180/714; TNA, Will of John West, 10 Sept. 1613, PROB 11/122/205; Guildhall Library (GL), Grocers' Company court minute book, 22 Aug. 1639-22 Sept. 1639, CLC/L/GH/B/o01/MS11588/o03, fos. 640, 644-6. For women's material gifts to guild companies in this period, see Jasmine Kilburn-Toppin, 'Gifting cultures and artisanal guilds in 
sixteenth- and early seventeenth-century London', The Historical Journal, 60 (2017), pp. 865-887, at p. 880.

${ }_{3}$ TNA, Kyte v. Grocers, 1677, C 7/200/142; Sherwood, ed., Endowed charities, pp. 237-8.

${ }^{64}$ Ian Archer, 'The arts and acts of memorialization in early modern London', in J. F. Merritt, ed., Imagining early modern London: Perceptions and portrayals of the city from Stow to Strype 15981720 (Cambridge, 2001), p. 90.

${ }_{55}$ Philip Norman, ed., Survey of London monograph 7, East Acton Manor House (7 vols., London, 1896-2010), vii, pp. 28-30.

${ }^{66}$ Richard Grassby, The business community of seventeenth-century England (Cambridge, 1995), p. 157; Grell, Dutch Church, pp. 257, 264; Kingsbury, Records, iii, p. 89.

${ }^{67}$ Moens, ed. Dutch Reformed Church, p. 211; Grell, Dutch Church, pp. 52, 299. For Katherine Hueriblock's endowment, see TNA, Will of Dame Katherine Viscountess Conway, 19 July 1639, PROB 11/180/714; and Norman, ed., Survey of London, vii, pp. 28-30.

${ }^{68}$ TNA, Secretary Conway to Mrs Cole, 1 Dec. 1628, State papers, 16/122 fo. 1. Louisa Cool's father, Mathias de Lobel, was James VI and I's herbalist. At this date, she was recently widowed. Jacob Cool's family had settled in Lime Street, where they practiced in the silk trade, and he was also made an elder of the Dutch church in 1624. After his death, the widowed Mrs Cool married Abraham Vanderdort in 1628, Curator of the Royal Collection, under Charles I. See, D. E. Allen, 'L'Obel, Mathias de (1538-1616), botanist'; and Ole Peter Grell, 'Cool, Jacob [Jacobus Colius; called Ortelianus] (1563-1628), scholar and writer', $O D N B$. Also, Helen Farquhar and Derek F. Allen, 'Abraham Vanderdort and the coinage of Charles I', The Numismatic Chronicle and Journal of the Royal Numismatic Society, 1 (1941), pp. 54-75. ${ }^{69}$ Kim Todt, “Women are as knowing therein as the men": Dutch women in early America', in Thomas A. Foster, ed., Women in early America (London, 2015), pp. 43, 46-7. For the education of English women in business, see Anne. L. Murphy, "You do manage it so well that I cannot do better": The working life of Elizabeth Jeake of Rye (1667-1736)', Women's History Review, https://doi.org/10.1080/09612025.2018.1455569, p. 9.

${ }^{70}$ Natasha Korda, 'Froes, rebatoes and other "outlandish comodityes": Weaving alien women's work into the fabric of early modern material culture', in Tara Hamling and Catherine Richardson, eds., Everyday objects: Medieval and early modern material culture and its meanings (Farnham, 2010), pp. 95-6. ${ }^{71}$ TNA, Will of Catharyne Hendriex, 12 Feb. 1619, PROB 11/133; TNA, Power of attorney from Sir Edward Conway... to Guillaume Van der Moyden, 30 Dec. 1619, State papers, 14/111, fo. 175. For her residence in London, see Kirk and Kirk, eds., Returns of aliens, ii, p. 470, iii, pp. 124, 126, 128-9. 
72 Whittle, 'Enterprising widows', p. 288; Schmidt, “'Assisting labour”, pp. 318-19; and Froide, Never married, pp. 106-7.

${ }^{73}$ For the association between Petticoat Lane and those occupied in the silk industry, see 'The Halifax estate in Spitalfields', in F. H. W. Sheppard, ed., Survey of London: Volume 27, Spitalfields and Mile End New Town (London, 1957), pp. 237-241. Accessed via British History Online <http://www.britishhistory.ac.uk/survey-london/vol27/pp237-241>.

${ }^{74}$ Erickson, 'Married women's occupations', p. 286.

75 TNA, Will of John West, 10 Sept. 1613, PROB 11/122/205.

${ }^{76}$ Lorena S. Walsh, Motives of honor, pleasure, and profit: Plantation management in the colonial Chesapeake, 1607-1763 (Chapel Hill, NC, 2010), pp. 65-6.

77 Grassby, Kinship and capitalism, pp. 92-3; Froide, Silent partners, pp. 101ff.

${ }^{78}$ Rabb, Enterprise and empire, p. 66; and Paul Hunneyball, 'Conway, Sir Edward I (c. 1563-1631)', History of Parliament.

79 Gillian T. Cell, 'The Newfoundland Company: A study of subscribers to a colonizing venture', William and Mary Quarterly, 22 (1965), pp. 611-625, at p. 625.

${ }^{80}$ See The Second Charter of Virginia (1609), in Brown, ed., Genesis of the United States, i, pp. 206-37; TNA, Will of Richard Fust, 9 Mar. 1614, PROB 11/123/266; TNA, Dr James Meddus to Secretary Conway, 26 July 1624, Fenchurch, State papers, 14/170, fo. 86.

${ }^{81}$ Sainsbury, ed., Calendar of state papers colonial, East Indies, ii, pp. 238-41; TNA, William Payne to Secretary Conway, 20 June 1626, London, State papers 16/30, fo. 66.

82 TNA, William Payne to Dr James Meddus, 30 June 1628, Highgate, State papers 16/108, fo. 126.

$8_{3}$ TNA, William Payne to Katherine Lady Conway, 2 Nov. 1627, n. p., State papers, 16/84, fo. 14.

84 TNA, Dr James Meddus to Katherine Viscountess Conway, 27 June 1628, Fenchurch, State papers, $16 / 108$, fo. 80.

${ }_{5}$ TNA, Dr James Meddus to Katherine Viscountess Conway, 25 July 1628, Fenchurch, State papers, 16/111, fo. 71 .

${ }^{86}$ See also Gillian T. Cell, English enterprise in Newfoundland, 1577-166o (Toronto, 1969), p. 78.

87 Froide, Silent partners, pp. 151, 176-7.

${ }^{88}$ Sharpe, ‘Gender at sea', p. 62-3; Spicksley, ‘Female investor', p. 289; Spicksley, 'Single women', p. 197; Todd, 'Property and a woman's place', p. 189.

${ }^{89}$ See Ferrar Papers, Magdalene College, Cambridge (FP), Annual accounts of earl of Southampton and Nicholas Ferrar, 22 May 1622-22 May 1623, no. 480; Certificate of Virginia Company, 12 May 1623, no. 
476; Interest and warrant, 23 Dec. 1620-22 May 1622, no. 383. On women lending by bond, see Spicksley, 'Single women', p. 195; Froide, Never Married, pp. 134-5.

$9^{\circ}$ Froide, Never married, p. 139.

${ }^{91}$ City of London, Livery Companies Commission, iv, pp. 457-477; and Sherwood, ed., Endowed charities, pp. 502-3.

92 LMA, Bridewell court book, 26 July 1617-13-Mar. 1626, CLC/275/MS33011/oo6; Peter Wilson Coldham, Child apprentices in America from Christ's Hospital, London 1617-1778 (Baltimore, MD, 1990). Also, Misha Ewen, “Poor soules”: Migration, labor, and visions for commonwealth in Virginia', in James Horn, Peter Mancall and Paul Musselwhite eds., Virginia in 1619: Slavery, freedom, and the emergence of English America (Chapel Hill, NC, forthcoming); and R. C. Johnson, 'The transportation of vagrant children from London to Virginia, 1618-1622' in Howard S. Reinmuth, ed., Early Stuart studies: Essays in honour of David Harris Wilson (Minneapolis, MN, 1970), p. 144.

93 Sandys was opposing his colleague in the Virginia Company, Sir Thomas Smythe, to represent Sandwich (Kent). See, Thrush, 'Sandys, Sir Edwin (1561-1629)', History of Parliament.

94 For this attempt, see Kupperman, Jamestown project, p. 293; Horn, Adapting to a new world, pp. 55-6; Theodore K. Rabb, Jacobean gentleman: Sir Edwin Sandys, 1561-1629 (Chichester, 1998), pp. 329-30.

95 On women as active investors, see Sharpe, 'Gender in the economy', pp. 301-2.

${ }^{96}$ Johnson, 'Lotteries of the Virginia Company', pp. 270ff.; TNA, Fitzwilliam v. West, Jan. 1615, STAC 8/144/6, fos. 1-2. For women who defrauded lotteries during the Financial Revolution, see Froide, Silent partners, pp. 176-7.

97 Craven, Dissolution of the Virginia Company, p. 33; and Kupperman, Jamestown project, p. 261.

98 TNA, Fitzwilliam v. West, Jan. 1615, STAC 8/144/6, fos. 1-2.

99 Jacob Selwood, Diversity and difference in early modern London (Farnham, 2010), pp. 73-4.

100 Dean, 'Elizabeth's lottery', p. 591.

101 TNA, Will of John West, 10 Sept. 1613, PROB 11/122/205.

102 New York Public Library, Richard Berkley to John Smyth, 3 Aug. 1633, MssCol 2799/42. For secrecy surrounding women's investments, see Froide, Silent partners, p. 71.

103 Katherine Hueriblock was said to be seventy-four when she died in 1639, and Rebecca Romney was described as an 'ancient matron' in 1642. Norman, ed., Survey of London, vii, pp. 28-30; Vicars, God on the mount (London, 1643), p. 128. 